\title{
Lack of evolutionary adjustment to ambient temperature in highly specialized cave beetles
}

\author{
Valeria Rizzo ${ }^{1}$, David Sánchez-Fernández ${ }^{1}$, Javier Fresneda², Alexandra Cieslak ${ }^{1}$ and Ignacio Ribera ${ }^{1 *}$
}

\begin{abstract}
Background: A key question in evolutionary biology is the relationship between species traits and their habitats. Caves offer an ideal model to test the adjustment of species to their surrounding temperature, as they provide homogeneous and simple environments. We compared two species living under different thermal conditions within a lineage of Pyrenean beetles highly modified for the subterranean life since the Miocene. One, Troglocharinus fonti, is found in caves at $4-11^{\circ} \mathrm{C}$ in the ancestral Pyrenean range. The second, T. ferreri, inhabits the coastal area of Catalonia since the early Pliocene, and lives at $14-16^{\circ} \mathrm{C}$.

Results: We found no differences in their short term upper thermal limit $\left(c a .50^{\circ} \mathrm{C}\right)$, similar to that of most organisms, or their lower thermal limit $\left(\mathrm{ca} .-2.5^{\circ} \mathrm{C}\right.$ ), higher than for most temperate insects and suggesting the absence of cryoprotectants. In longer term tests ( 7 days) survival between $6-20^{\circ} \mathrm{C}$ was almost $100 \%$ for both species plus two outgroups of the same lineage, but all four died between $23-25^{\circ} \mathrm{C}$, without significant differences between them.

Conclusions: Our results suggest that species in this lineage have lost some of the thermoregulatory mechanisms common in temperate insects, as their inferred default tolerance range is larger than the thermal variation experienced through their whole evolutionary history.
\end{abstract}

Keywords: Acclimation, Adaptation, Pyrenees, Thermal tolerance, Subterranean environment

\section{Background}

One of the main questions in evolutionary biology is to link the phenotype of an organism to the environment in which it lives. This link is usually masked by the complexity of both the environmental factors that may influence an organism and its response to these factors $[1,2]$, posing a major challenge to the understanding of the origin of phenotypic traits. Under natural conditions species are exposed to continuously changing and interacting climatic factors [3], to which they can adjust by behavioural plasticity, change of microhabitat or by migration $[2,4]$.

The deep subterranean environment seems an ideal scenario to study the evolutionary adjustment of the species to their environments, as many of these confounding factors are completely absent from it. In the deepest parts of the caves and their surrounding network of fissures the conditions of the habitat are extremely

\footnotetext{
* Correspondence: ignacio.ribera@ibe.upf-csic.es

${ }^{1}$ Institute of Evolutionary Biology (CSIC-Universitat Pompeu Fabra), Passeig

Maritim de la Barceloneta 37-49, 08003 Barcelona, Spain

Full list of author information is available at the end of the article
}

constant and homogeneous, with a permanent darkness and nearly constant temperature and humidity $[5,6]$. Subterranean organisms have a very limited range of options to behaviourally exploit local climatic heterogeneity -as there is virtually none-, and their general lack of mobility [5,6] also reduces the possibility of migration when conditions become unfavourable. In addition, the general scarcity of resources imposes stringent requirements on the species living in this environment, resulting in simple, low diverse communities $[7,8]$.

Caves have a homogeneous and constant temperature through the year, approximately equal to the average annual temperature of the surface $[5,9]$, but for any given lineage of subterranean organisms this temperature may vary both geographically (including altitudinal changes) and temporally (past climatic change). It could be expected that given the harsh conditions and the stability of the environment species should have fine-tuned their thermal tolerance to the temperatures of their habitats [10-12]. For example, in a similarly constant and homogeneous environment, the cold Antarctic waters, the most stenotherm species cannot survive an increase of 
$2-5^{\circ} \mathrm{C}$ above the temperature they currently experience (below $2^{\circ} \mathrm{C}$ ) [13]. Cave organisms are thus an ideal model to test the long term evolutionary adjustment of organisms to the temperature of their habitats [14], although there is very limited information available on their comparative thermal tolerances (see Discussion).

The Pyrenean chain in the Iberian peninsula is one of the world hotspots of subterranean diversity $[15,16]$. Two monophyletic radiations of beetles are particularly rich, with hundreds of narrow endemic species: Trechini $[17,18]$ (Carabidae) and Leptodirini [19,20] (Leiodidae). Within the Pyrenean Leptodirini, there was a single colonisation of the subterranean environment in the Early Miocene, leading to a radiation of more than 140 subterranean species distributed through the chain [20]. Only in one occasion these species expanded their range outside the Pyrenees, with the colonisation of coastal areas of Catalonia during the early Pliocene by a member of the genus Troglocharinus that subsequently diversified in isolated karstic areas [21]. The caves occupied by the species in the coastal area are on average $5^{\circ} \mathrm{C}$ warmer than those occupied by the species of the ancestral range in the Pyrenees (average temperature of the caves in the coast $14.2 \pm 1.0^{\circ} \mathrm{C}$; in the Pyrenees $8.9 \pm 1.9^{\circ} \mathrm{C}$ ), offering a unique opportunity to study the long term evolutionary adjustment of the species to their surrounding temperatures and the possible persistence of regulatory or acclimation mechanisms.

In this work we test the thermal tolerance of two species of Troglocharinus, one from the ancestral area in the Pyrenees ( $T$. font $i$ Jeannel) currently living in caves at ca. $4-11^{\circ} \mathrm{C}$, and another from the coast (T. ferreri Reitter), found in caves between $14-16^{\circ} \mathrm{C}$. We compare their short term upper (UTL) and lower critical thermal limits (LTL) as well as their longer term survival at a range of temperatures encompassing those they experience under natural conditions, or were likely to have experienced in their evolutionary history (as estimated from palaeoclimatic data). In addition to the two species of Troglocharinus, for the long term experiments we also studied two related Pyrenean species, one (Trapezodirus arcticollis Jeannel) within the same highly derived subterranean lineage of Troglocharinus, and another (Macharoscelis infernus Dieck) more distantly related (with a common ancestor ca. 24 Ma [20], Figure 1).

Using an experimental approach we aim to study the evolutionary adjustment of cave species to their surrounding temperatures by testing 1 ) if there is any significant difference in the short term thermal limits between the species living in the coast ( $T$. ferreri) and the species living in the Pyrenees (T. fonti); 2 ) if there is any difference among the studied species in their longer term (up to 7 days) thermal tolerance at a range of subcritical temperatures; and 3) if there is any sign of acclimation to changing temperatures within their tolerance ranges.

The combination of an experimental approach with data on the current and past temperatures allows a better understanding of the long term evolutionary dynamics of the thermal biology of subterranean species, and its potential role in their geographical expansion and diversification. The knowledge of their thermal tolerances should also be of interest for the conservation prospects of these species, given their limited possibilities to track suitable conditions when confronting global change.

\section{Methods}

\section{Short term experiments}

For the short term thermal tolerance experiments we used two species of the genus Troglocharinus, one from

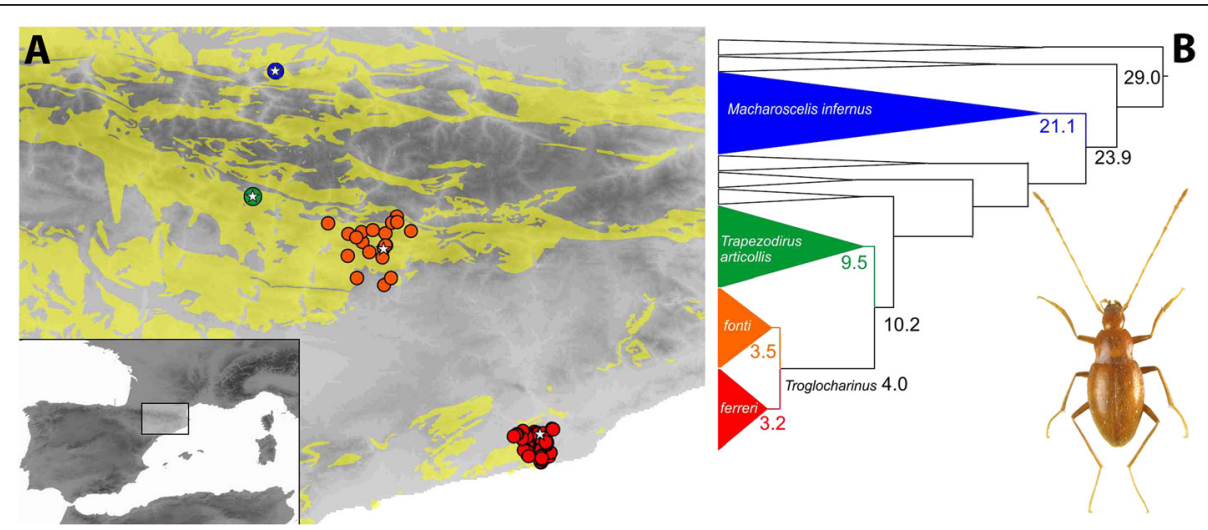

Figure 1 Study system. A) Geographical distribution of the species used in the experiments and B) phylogenetic relationships among them (modified from ref. [20]). Yellow background areas in the map, distribution of the limestone. Coloured circles, caves known to have the species; with a star, the cave from which the studied specimens were collected ( $M$. infernus and $T$. arcticollis are only known from a reduced number of caves in close proximity, and their ranges are represented by a single circle). Numbers in the nodes, millions of years before present. Photo habitus, Troglocharinus ferreri. 
the warmer coastal area (T. ferreri) and another from the ancestral geographic range within the Pyrenees (T. fonti) [21]. Specimens of T. ferreri were collected by hand in Cova de Coll Verdaguer (Garraf massif), with a temperature range of $14-16^{\circ} \mathrm{C}$ (Figure 1; Table 1) using baits and food traps set $24 \mathrm{~h}$ in advance. Specimens were placed in a portable fridge at ca. $14^{\circ} \mathrm{C}$ and $85 \% \mathrm{RH}$, with substratum from the cave and moss from the entrance to retain humidity, and kept and transported in the same conditions to the place where the experiments were conducted (University of Murcia, Spain).

Specimens of T. fonti were collected by hand in Cova d'Ormini (Pyrenees), at a temperature of $6-8^{\circ} \mathrm{C}$ (Figure 1; Table 1). Specimens were handled and stored in the same conditions as those used for T. ferreri, with the only exception of the temperature in the portable fridge, set to ca. $7^{\circ} \mathrm{C}$.

To obtain an estimate of the average current temperature of the caves and associated subterranean environment in which the species are found we used the mean annual temperature at a 0.08 degree spatial resolution from WORLDCLIM, version 1.3 (www.worldclim.org [22]). The deep subterranean environment is known to have a constant temperature approximately equal to the average annual temperature of the surface [5,9]. To estimate the temperature during the Last Glacial Maximum (LGM; 21,000 YBP) we used a simulation of the general circulation model (GCM) from the Community Climate System Model (CCSM, http://www2.cesm.ucar.edu/ [23]). The original GCM data were downloaded from the PMIP2 website (https://pmip2.lsce.ipsl.fr/). For the Last Interglacial (LIG; $120,000-140,000$ YBP) we used the data provided by [24], available at www.worldclim.org (Table 1).

For the experiments we used a FLIR SC305 infrared camera (FLIR Systems, Portland, US), with a resolution of $320 \times 240$ pixels and sensitivity $<0.05^{\circ} \mathrm{C}$ at $30^{\circ} \mathrm{C}$. The camera was connected to a computer using the ThermaCam Researcher Professional 2.10 software (FLIR Systems). Beetles were video taped in a climatic chamber BINDER MK53 (BINDER, Tuttlingen, Germany; range $-50^{\circ}$ to $180^{\circ} \mathrm{C}, \pm 0.3^{\circ} \mathrm{C}$ ). During the experiments, specimens were fixed on their elytra with paper glue or bee wax.
Experiments to determine the lower thermal limit (LTL) started at a temperature close to the range found in the caves of origin, with a decreasing ramping temperature of $1^{\circ} \mathrm{C} / \mathrm{min}$ and an initial $\mathrm{RH}$ of $60-70 \%$. Body temperature was continually recorded, with data logging at intervals of ca. 1". The temperature considered as the LTL was the supercooling point $[25,26]$, that is, the point at which a sudden increase of body temperature was recorded, indicating the release of latent heat due to freezing (Figure 2A). We do not have evidence of freezing tolerance in any of the studied species, neither from our experiments nor from published data. Experiments were continued until $-20^{\circ} \mathrm{C}$.

For the upper thermal limit (UTL) we set up an increasing ramping program with the same general conditions as before. Upper thermal limit (i.e. the lethal temperature) was considered to be the point at which specimens stopped moving for more than a minute, as recorded by a video camera and observed through a visor by two different observers (e.g. [27]). Experiments were stopped at $60^{\circ} \mathrm{C}$. We did not attempt to measure the critical thermal maximum (CTmax) as with glued specimens it was difficult to estimate the point at which they loose control of their movements. In the long term experiments it was also not possible to determine the CTmax (see below), the UTL being thus the only comparable measure between the two types of experiment.

For Troglocharinus fonti (the Pyrenean species) we did two replicates of 12 specimens for each the UTL and the LTL. For T. ferreri (the coastal species), and due to the limited availability of specimens, we did a single experiment of 12 specimens each for UTL and LTL.

\section{Long term experiments}

To have an estimation of thermal tolerances at more ecologically relevant conditions we set up a series of experiments using survival at longer times and temperature increases at slower rates. We used the same two species as before (the coastal Troglocharinus ferreri and the Pyrenean $T$. font $i$ ), plus two outgroups of the same lineage to establish the polarity of any potential change between the two Troglocharinus species. The species used as outgroups were Trapezodirus arcticollis and Macharoscelis infernus,

Table 1 Caves from which the studied specimens were collected

\begin{tabular}{lllllll}
\hline Species & Cave & Lat. & Long. & Range T current & Range T LGM & Range T LIG \\
\hline T. ferreri & Cova de Coll Verdaguer, Vallirana & 41.393 & 1.911 & $13.9-16.2$ & $9.4-11.7$ & $13.9-16.3$ \\
T. fonti & Cova d'Ormini, Montanisell & 42.207 & 1.226 & $4.2-10.9$ & $(-0.6)-6.2$ & $4.30-10.9$ \\
T. articollis & Cova de St Salvador, Bonansa & 42.437 & 0.653 & 6.9 & 2.1 & 7.0 \\
M. infernus & Gouffre du Béguet, Juzet d'Izaut & 42.987 & 0.751 & $8.7-10.1$ & $5.5-6.0$ & $8.8-10.2$ \\
\hline
\end{tabular}

Data include geographical coordinates (see Figure 1), range of temperatures in which the species is currently found, estimated range of temperatures of the Last Glacial Maximum (LGM; 21,000 YBP), and range of temperatures of the Last Interglacial (LIG; 120,000-140,000 YBP). 

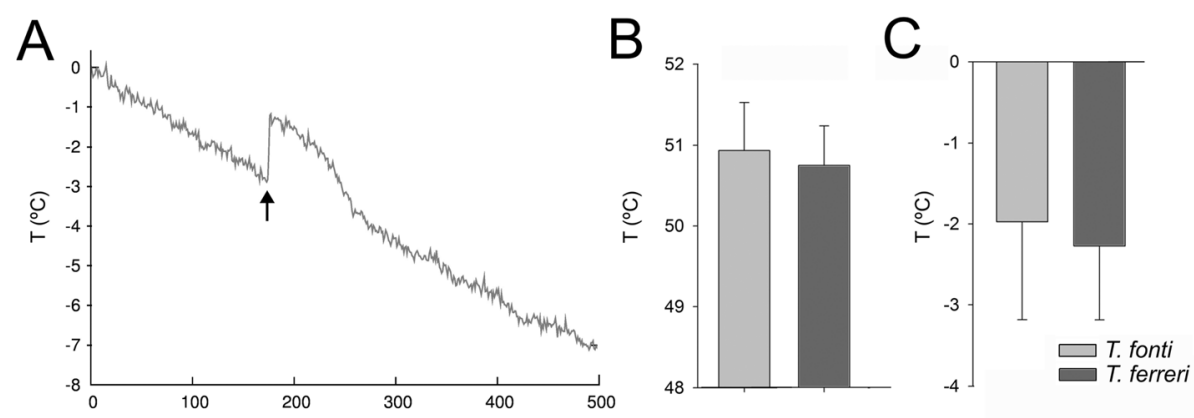

Figure 2 Results of the short term experiments for the Pyrenean (T. fonti) and coastal (T. ferreri) species of Troglocharinus. A) Example graph of the lower thermal limit (LTL) experiment. The arrow marks the point at which the specimen froze (i.e. the supercooling point), with the sudden liberation of latent (or crystallization) heat, considered to be the LTL. B) Upper thermal limit (UTL). C) LTL. Columns, average temperature at which specimens died, with standard deviation.

both from the Pyrenees (see Figure 1 and Table 1 for the location and conditions of the caves; and ref. [20] for the phylogenetic relationships and divergence times between the four species).

Specimens were collected by hand in the caves and transferred to the laboratory under controlled conditions, with substratum from the cave and some moss to keep humidity. In the laboratory, specimens were acclimated and stored previous to the experiments at the approximate temperature of the cave (see Table 1) in a Liebherr WTes 4177 cabinet (Bulle, Switzerland), which can establish a continuous gradient of temperature between $5-18^{\circ} \mathrm{C}$, in closed plastic containers $(30 \times 21 \times 6.5 \mathrm{~cm})$ with moss and substratum from the caves (the "stock"). Specimens were kept in these conditions, considered to be closer to the natural conditions in the cave, without being disturbed until used for the experiments. For the experiments, specimens were placed in smaller plastic boxes $(13 \times 8 \times 5.5 \mathrm{~cm})$ with a $0.5 \mathrm{~cm}$ white plaster substratum, ca. 10 volcanic stones of a diameter of 1-3 cm saturated with distilled water, and white tissue paper also saturated in distilled water. Specimens in the experimental boxes were fed ad libitum with freshly frozen Drosophila melanogaster. Some of the control specimens were kept in the same experimental boxes for more than nine months after the end of the experiments, indicating that the observed mortality was mostly due to the temperature treatments and not to stressing conditions or a reduced longevity (which in any case would have affected both control and treatment specimens equally).

For the experiments, the box with the specimens to be treated (usually replicas of 10 individuals) was placed in a Nüve TK120 (Ankara, Turkey) climatic test cabinet (temperature range $-10^{\circ} \mathrm{C} / 60^{\circ} \mathrm{C}$, relative humidity, $\mathrm{RH}$, range $20-95 \%)$. Controls were kept in the cabinet at the approximate temperature of the cave and $\mathrm{RH}$ close to saturation. The actual temperature and $\mathrm{RH}$, or temperature only, inside the experimental boxes were recorded every 30" during the experiments with data loggers Testo (Lenzkirch, Germany) $176 \mathrm{H} 1 \quad\left(\mathrm{~T} \pm 0.2^{\circ} \mathrm{C}\right.$, $\mathrm{RH} \pm 0.1 \%)$ or Testo $176 \mathrm{~T} 4\left(\mathrm{~T} \pm 0.5^{\circ} \mathrm{C}\right.$, with $\mathrm{Cu}-\mathrm{C}$ termopars) (Additional file 1: Table S1). Specimens were checked every $24 \mathrm{~h}$, the stones and the tissue wetted and fresh food added whenever necessary. Specimens were recorded as alive when they were capable of some movement or dead when there was no movement after being poked at. We did not attempt the potential recovery of specimens apparently moving uncoordinatedly, as all life specimens were immediately returned to the incubator to minimise disturbance of the experimental conditions. No specimen considered to be dead recovered after being retired from the experimental boxes.

Experiments were conducted in replicas of 10 specimens each, including a control kept in the same conditions at the approximate temperature of the cave $\left(12^{\circ} \mathrm{C}\right.$ for $T$. ferreri; $7^{\circ} \mathrm{C}$ for $T$. fonti; $6^{\circ} \mathrm{C}$ for $T$. articollis and $10^{\circ} \mathrm{C}$ for $M$. infernus; Additional file 1: Table S1), and with specimens taken directly from the stock. When the number of specimens was insufficient we used smaller replicas, and when there was no mortality the same control could be re-used for successive experiments, occasionally with less than ten individuals (Additional file 1: Table S2). We conducted three types of experiments: 1) Survival at different temperatures: treated specimens were placed directly from the stock to a set temperature $\left(6,20,23\right.$ or $25^{\circ} \mathrm{C}$, plus controls) and survival recorded for up to 7 days. 2) Acclimation at ramping temperatures: starting at $20^{\circ} \mathrm{C}$, the temperature was raised $1^{\circ} \mathrm{C}$ every $48 \mathrm{~h}$, until all specimens died. 3) Acclimation at fixed temperatures: specimens were acclimated for seven days at 6 or $12^{\circ} \mathrm{C}$ and then transferred to $23^{\circ} \mathrm{C}$ (Additional file 1: Table S2).

\section{Statistical analyses}

For the comparison of the results of the short term experiments we used non-parametric statistical tests 
(Mann-Whitney U-test), as the dependent variable does not follow a normal distribution. We nonetheless computed parametric t-tests for comparison and to test the robustness of the results. For the long term experiments we also used non-parametric Mann-Whitney U-tests and Kruskal-Wallis to compare the survival at different temperatures, with multiple comparison tests to detect significant differences between means. Similarly, despite the non-normality of residuals we analysed the data through the use of generalized linear models (GLM) assuming a Poisson distribution and with post-hoc tests using the Bonferroni correction to identify significant differences among groups. All statistical analyses were conducted using SPSS 15.0.1 and Statistica 8.0.

\section{Results}

\section{Short term experiments}

When measured using a fast temperature increase $\left(1^{\circ} \mathrm{C} / \mathrm{m}\right)$ the average upper thermal limit (UTL) of the specimens tested was around $50^{\circ} \mathrm{C}$, with no significant differences between the species in the Pyrenees (Troglocharinus fonti, $\left.\mathrm{UTL}=50.9^{\circ} \mathrm{C}, \mathrm{sd}=0.59\right)$ and the coastal region $(T$. ferreri, $\left.\mathrm{UTL}=50.7^{\circ} \mathrm{C}, \mathrm{sd}=0.49\right)(\mathrm{M}-\mathrm{W}$ U-test: $\mathrm{U}=75.5, \mathrm{p}=0.06$; t-test: $\mathrm{t}$-value $=0.90$, d.f. $=32, \mathrm{p}=0.37$; Figure $2 \mathrm{~B}$ and Additional file 1: Table S2A).

Using the same speed of temperature change, the average lower thermal limit (LTL) was again not significantly different between species ( $T$. ferreri, LTL $=-2.4^{\circ} \mathrm{C}$, $\mathrm{sd}=0.91 ; T$. fonti, LTL $=-2.1^{\circ} \mathrm{C}$, sd $1.21 ; \mathrm{M}-\mathrm{W}$ U-test: $\mathrm{U}=109, \mathrm{p}=0.31 ; \mathrm{t}$-test: $\mathrm{t}$-value $=0.75$, d.f. $=33 ; \mathrm{p}=0.46$; Figure $2 \mathrm{C}$ and Additional file 1: Table S2A). The increase in temperature due to the release of the latent heat when the tissue froze at the supercooling point was around $1^{\circ} \mathrm{C}$ for both species, and the temperature of the specimens took on average ca. 2 minutes to match again the ambient temperature (Figure 2A and Additional file 1: Table S2A). The decrease in body temperature was perfectly linear for both species, in synchrony with the decrease of ambient temperature, with the only interruption of the release of the latent heat (Figure 2A). There was thus no indication of temperature compensation or regulation in any of the two species tested.

\section{Long term experiments}

For the long term experiments results using nonparametric Kruskal-Wallis ANOVA $(\mathrm{K}-\mathrm{W}), \mathrm{t}$-tests and GLM were very similar, so the latter are reported only when there were differences (see Additional file 1: Table S3 for a full account of GLM results).

\section{Survival at different temperatures}

For all species there were significant differences in the long term survival (7 days) at different temperatures (control, 6, 20, 23 and $\left.25^{\circ} \mathrm{C}\right)(\mathrm{K}-\mathrm{W}$ test: $\mathrm{H}(4, \mathrm{~N}=351)=$
250.61, $\mathrm{p}<0.0001)$. Survival at $6^{\circ} \mathrm{C}$, controls and $20^{\circ} \mathrm{C}$ was in all cases almost $100 \%$ at the end of the test the 7 th day. On the contrary, survival at $25^{\circ} \mathrm{C}$ was always less than $24 \mathrm{~h}$ (Figure 3 and Additional file 1: Table $\mathrm{S} 2 \mathrm{~B}$ ). Survival at $23^{\circ} \mathrm{C}$ was more variable (Figure 3), but still overall differences among species were not significant $(\mathrm{K}-\mathrm{W}$ test: $\mathrm{H}(3, \mathrm{~N}=351)=3.13, \mathrm{p}=0.37)$, and when compared using GLM models and a Bonferroni correction the interaction between species and treatment did not result in significant differences $(\mathrm{p}=0.26$, Additional file 1: Table S3).

\section{Acclimation at ramping temperatures}

There were significant differences among species in an overall comparison of the survival when acclimated with an increase of $1^{\circ} \mathrm{C}$ every $48 \mathrm{~h}$ (starting from $\left.20^{\circ} \mathrm{C}\right)(\mathrm{K}-\mathrm{W}$ test: $\mathrm{H}(2, \mathrm{~N}=25)=11.15, \mathrm{p}<0.005)$. Pairwise differences were, however, only significant between the coastal T. ferreri and the most distant outgroup species tested (M. infernus), not between the coastal and Pyrenean species of Troglocharinus. Specimens of T. ferreri survived on average longer than those of $M$. infernus, but in any case none of the specimens survived more than $24 \mathrm{~h}$ at $25^{\circ} \mathrm{C}$ (Table 2A).

\section{Acclimation at fixed temperatures}

There were no significant differences in survival at $23^{\circ} \mathrm{C}$ between the specimens acclimated at the control temperatures and individuals acclimated for one week at a different temperature $\left(6^{\circ} \mathrm{C}\right.$ for $T$. ferreri, M-W U-test, $\mathrm{U}=67.5, \mathrm{p}=0.49 ; 6$ and $12^{\circ} \mathrm{C}$ for $T$. fonti, $\mathrm{K}-\mathrm{W}$ test: $\mathrm{H}$ $(2, \mathrm{~N}=56)=5.92, \mathrm{p}=0.052$ ) (Table $2 \mathrm{~B}$ and Additional file 1: Table S2).

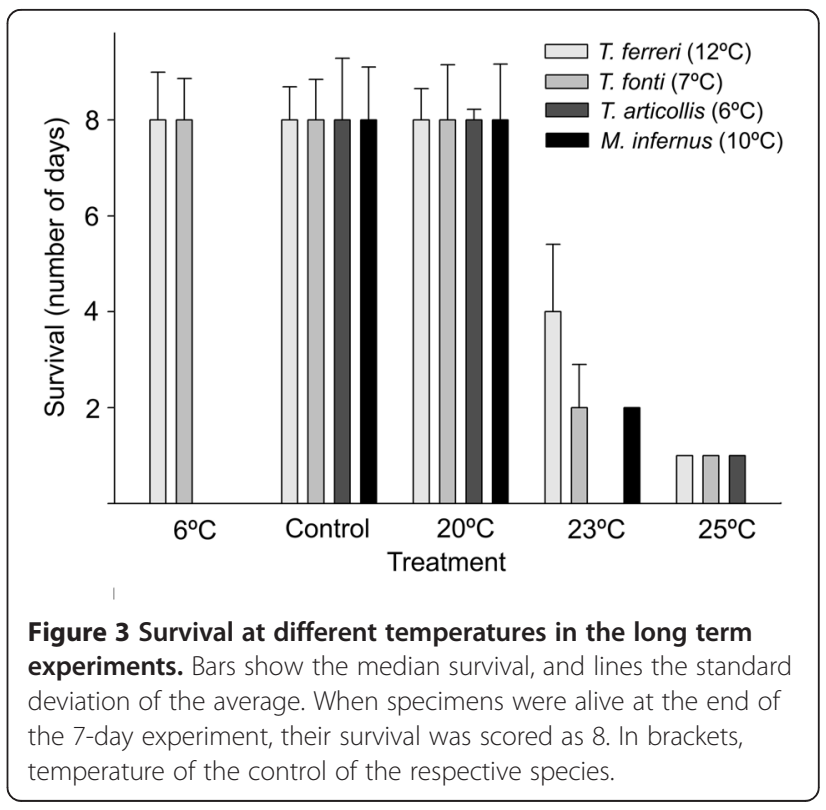


Table 2 Results of the acclimation experiments

\begin{tabular}{llllll}
\hline A) & $\mathbf{n}$ & $\mathbf{T}^{\circ} \mathbf{C}$ & Min. & Max. & Std.Dev. \\
T. ferreri & 9 & 24.3 & 22 & 25 & 1.1 \\
T. fonti & 10 & 23.6 & 21 & 24 & 1.0 \\
M. infernus & 6 & 22.2 & 20 & 23 & 1.2 \\
B) & & No. days & Min. & Max. & Std.Dev. \\
T. ferreri $\left(6\right.$ to $\left.23^{\circ} \mathrm{C}\right)$ & 9 & 3.3 & 2 & 5 & 1.32 \\
T. ferreri $\left(12 \text { to } 23^{\circ} \mathrm{C}\right)^{*}$ & 10 & 4.3 & 2 & 7 & 1.89 \\
T. fonti $\left(6\right.$ to $\left.23^{\circ} \mathrm{C}\right)$ & 7 & 2.0 & 1 & 3 & 0.82 \\
T. fonti $\left(7 \text { to } 23^{\circ} \mathrm{C}\right)^{*}$ & 16 & 2.2 & 1 & 3 & 0.75 \\
T. fonti $\left(12\right.$ to $\left.23^{\circ} \mathrm{C}\right)$ & 8 & 3.7 & 2 & 5 & 1.16 \\
\hline
\end{tabular}

A) Ramping temperatures (average survival temperature); B) fixed temperatures (average number of surviving days). With asterisks, control treatments.

\section{Discussion}

The homogeneity and stability of the deep subterranean environment, both at ecological and evolutionary scales, would lead to the expectation of a close match between the thermal tolerance of the species living in it and the surrounding temperatures $[10,11]$. This expectation was only partially fulfilled. The maximum viable temperature range for all studied species (between close to $0^{\circ} \mathrm{C}$ to $23^{\circ} \mathrm{C}$ ) was much narrower than that of non subterranean insects living at the same latitude, indicating that subterranean species in this lineage do have a modified thermal biology. However, there were no significant differences between species living in caves at substantial different temperatures.

Thus, the supercooling point of the species of Troglocharinus living in the Pyrenees and the one living in the coastal area were the same $\left(\mathrm{ca} .-2.5^{\circ} \mathrm{C}\right)$, and higher than that of most species of temperate invertebrates [26,28], including other species of surface Coleoptera (see e.g. [27,29-32] for measures obtained using the same methods). The supercooling point of the studied subterranean species is probably close to the freezing temperature of hemolymph without the presence of additional osmoregulation or antifreezing substances, which has been estimated at $-2.79^{\circ} \mathrm{C}$ for a hemolymph osmolality of 1.5 osmoles [26].

Some subterranean Leptodirini of the same Pyrenean lineage are known to live in caves with permanent snow and ice at ca. $2-3^{\circ} \mathrm{C}$, such as some species of Paratroglophyes, or Speonomites kryophilos (Fresneda \& Hernando) ([33]:page 571, [34]). However, due to the stability of the subterranean environment this temperature is maintained around the same value through the year, without substantial fluctuations and not reaching sub-zero temperatures. Caves at below zero temperatures are likely to be uninhabitable as water should not be available in liquid form at any time of the year. This suggests that in this lineage of cave beetles species have lost the capability to sustain low supercooling temperatures, thus avoiding the metabolic cost of synthesizing the cryoprotectants usually present in temperate insects $[25,26]$.

We did not find differences between species in the upper thermal limits when measured in a short term ramping experiment, which in this case were similar to those found in other beetles of the same latitude (around $40-50^{\circ} \mathrm{C}$, e.g. [27,29-32]), and similar to that of most eukaryotic species [28]. It seems likely that, with the exception of species living in extreme environments such as deep oceanic vents or hydrothermal sources, most short term measures of upper thermal tolerance can only be related to general biochemical or physiological constraints, and in particular to the denaturation temperature of most proteins [35]. The lack of adjustment of the short term measure of the UTL with local conditions seems to be a common pattern in terrestrial animals (e.g. [36-38]), and its ecological or evolutionary interpretation (e.g. [39]) may thus be debatable.

In sharp contrast to the estimated short term UTL, none of the species tested could survive more than $24 \mathrm{~h}$ at $25^{\circ} \mathrm{C}$, and the survival at $23^{\circ} \mathrm{C}$ was also limited to $2-3$ days, unlike most surface terrestrial species in temperate regions. Data on the development of some species of the same evolutionary lineage support this strict thermal limitation, with $100 \%$ egg mortality between $15-21^{\circ} \mathrm{C}$ [40]. The proximate cause of mortality of terrestrial animals at subcritical temperatures (i.e. pejus temperatures in the sense of [41]), and specially the role of oxygen deprivation, is controversial [42-44]. For subterranean species oxygen accessibility is complicated by the water saturated atmosphere in the cave and the increased permeability of their integument, which may blur the distinction between aquatic and terrestrial habits (as in some species of "amphibious" Leptodirini, e.g. [45,46]). In any case, it seems likely that given the narrow range of tolerated temperatures and the high mortality $(100 \%$ in less than $24 \mathrm{~h}$ at $25^{\circ} \mathrm{C}$ ) temperature limitation must be the result of a strong physiological constraint rather than the cumulative effect of an increased metabolic rate.

Contrary to expectations, we did not find differences in the long term thermal tolerance of the Pyrenean and the coastal species. In our tests, at 6 and $20^{\circ} \mathrm{C}$ the survival of the adults was in all species close to $100 \%$ at seven days. Although this time may be insufficient to assess the long term effect of subcritical (pejus) temperatures, it excludes the possibility of marked differences between the coastal and Pyrenean species of Troglocharinus, as $20^{\circ} \mathrm{C}$ is above the temperature experienced by both species in their recent evolutionary history, and $6^{\circ} \mathrm{C}$ is below that experienced by the coastal species since their range expansion in the early Pliocene [21] (see below and Table 1). We did not find clear signs of acclimation, specially in the two Troglocharinus species tested. Some results suggest the possibility of 
some differences in acclimation to slow ramping temperatures with respect to the most distantly related outgroup (Macharoscelis infernus), but in any case these differences were limited to a longer survival at intermediate temperatures, maintaining the same absolute thermal limits. Some of the developmental data available also suggest the possibility of long term acclimation, as the optimal temperatures for larval development are reported to vary depending on the temperature at which the parents were reared -but again never reaching beyond the same absolute thermal limits [40].

All evidence thus suggest that species in this lineage of Pyrenean subterranean beetles have lost some of the physiological mechanisms linked to thermal tolerance commonly present in temperate insects, and it can be hypothesized that they reflect the default limits inherited from their most closely related surface relatives in the early Miocene (Figure 1). This does not seem to be the case for other lineages of subterranean Leptodirini in different geographical areas, such as the genus Neobathyscia in northeast Italy. Some species in this genus have retained resistance to sub-zero temperatures even if they do not experience them in their current habitat, with the freezing temperature (also measured as the release of latent heat at the supercooling point) between $-6^{\circ} \mathrm{C}$ and $-8^{\circ} \mathrm{C}$ in species living at different depths in the cave [47]. They also have a better tolerance to higher temperatures [14] and have been shown to retain an HSP70 heat shock response, which also differs between species according to their current habitat [48]. It is likely that Neobathyscia derives from surface ancestors that diverged from the Pyrenean lineage at least since the middle Eocene [19,20], but its precise phylogenetic position and the age of the colonization of the subterranean environment are unknown. In this case, the retention of a wider tolerance can be linked to the current habitat (with the species living closer to the entrance having a wider tolerance), and possibly to a more recent origin of the strictly subterranean adaptations [47].

Other subterranean organisms have been shown to have thermal tolerances broader than the extremely narrow range of temperatures of their current environment, such as e.g. some European stygobiont Crustaceans $[49,50]$. Although some species were sensitive to changes of only $2^{\circ} \mathrm{C}$ above or below their habitat temperature, others were able to tolerate without problems changes of more than $10^{\circ} \mathrm{C}$ [49]. However, in this case the wider thermal tolerance was interpreted to be the result of the changes in temperature experienced during the Pleistocene [50], while in the species of Troglocharinus the tolerance goes beyond the temperatures experienced through their entire evolutionary history. The highest temperatures currently experienced by the species of the genus are those in the coastal area of Catalonia, with a maximum of ca. $16^{\circ} \mathrm{C}$ in T. ferreri. During the Miocene thermal optimum (16-14 Ma), with temperatures up to $3-4^{\circ} \mathrm{C}$ higher that at present [51], there were no Leptodirini in the coastal area, as the colonization occurred during the early Pliocene [21]. In the Pyrenean range, an increase of $3-4^{\circ} \mathrm{C}$ would still maintain the temperature of the caves below $20^{\circ} \mathrm{C}$. Through the Pleistocene glacial periods the Pyrenean caves currently inhabited by Leptodirini suffered a decrease of $4-5^{\circ} \mathrm{C}$ (Table 1) but still maintained temperatures above zero, with only very few exceptions of caves assumed to have been recently colonized. Thus, a default tolerance range between temperatures close to the freezing point of water and ca. $20^{\circ} \mathrm{C}$ may have sufficed these beetles for the last 30 Million years, allowing them to dispense of any costly regulatory mechanism. If this were the case, some of the coastal populations of Troglocharinus may be now close to their physiological limit, which added to their reduced mobility and habitat confinement increases the concerns on their long term survival.

\section{Conclusions}

In this manuscript we provide the first data on the thermal tolerance of terrestrial organisms strictly restricted to the deep subterranean environment, an ideal scenario for testing the long term adjustment of organisms to their environments. We hypothesise that these species have lost some of the physiological mechanisms related to thermal tolerance due to their likely metabolic cost in a stable environment but with severe resource restrictions. This has been possible because the "default" range (i.e. the thermal tolerance without added resistance mechanisms) was enough to allow them to survive in the constant environment of the caves through their evolutionary history. There are two main conclusions that could be inferred from our work: 1) even under what seem ideal conditions to expect a fine adjustment to temperature, other factors (in this case possibly the scarcity of resources) can override this adjustment, so that different taxa under different conditions may have similar broad tolerances; and 2) this should be a strong cautionary warning for studies trying to infer physiological tolerances from characteristics of the environment only, specially considering that in most cases organisms have many different ways to use the temporal and spatial heterogeneity of the habitat to accommodate their needs.

\section{Availability of supporting data}

All raw data are included in the Supplementary files. 


\section{Additional file}

Additional file 1: Table S1. Temperature $(T)$ and relative humidity $(\mathrm{RH})$ at the different experimental conditions, as measured with the data loggers. Table S2. Results of the experiments of thermal tolerance. Table S3. Results of the Generalized Linear Model (GLM) analyses.

\section{Competing interests}

The authors declare that they have no competing interests.

\section{Authors' contributions}

VR, AC and IR conceived the study. VR, JF, AC and IR obtained the specimens. VR and IR conducted the experiments. VR, DSF and IR analysed the data. All authors contributed to the writing and improving the manuscript, and approved the final version.

\section{Acknowledgements}

We thank Charles Bourdeau, Hervé Brustel, Jordi Comas, Olivier Courtin, Arnaud Faille and Josep Pastor for help in the collection of the specimens; Diego Nieto-Lugilde for help with paleotemperature data; Josefa Velasco, Susana Pallarés, José A. Carbonell (Universidad de Murcia) and Rocío Alonso and Pau Balart (IBE, Barcelona) for help with the experiments; and four anonymous reviewers for comments and suggestions. We also thank the Parc del Garraf and his Director Santiago Llacuna for his support and for collecting permits. No permits or ethical approval were required for the experimental procedures. This work was partly funded by project CGL201015755 from the Spanish Government to IR.

\section{Author details}

'Institute of Evolutionary Biology (CSIC-Universitat Pompeu Fabra), Passeig Maritim de la Barceloneta 37-49, 08003 Barcelona, Spain. ${ }^{2}$ Museu de Ciències Naturals (Zoologia), Barcelona, Spain.

\section{Received: 5 September 2014 Accepted: 15 January 2015}

\section{Published online: 04 February 2015}

\section{References}

1. Dawson TPS, Jackson T, House Jl, Prentice IC, Mace GM. Beyond predictions: biodiversity conservation in a changing climate. Science. 2011;332:53-8.

2. Sunday JM, Bates AE, Kearney MR, Colwell RK, Dulvy NK, Longino JT, et al. Thermal-safety margins and the necessity of thermoregulatory behavior across latitude and elevation. Proc Natl Acad Sci U S A. 2014;111:5610-5.

3. Uvarov BP. Insects and climate. T Roy Ent Soc London. 1931;79:1-232.

4. Bernardo J. Biologically grounded predictions of species resistance and resilience to climate change. Proc Natl Acad Sci U S A. 2014;111:5450-1.

5. Culver DC, Pipan T. The biology of caves and other subterranean habitats. Oxford: Oxford University Press; 2009.

6. Juan C, Guzik MT, Jaume D, Cooper SJ. Evolution in caves: darwin's 'wrecks of ancient life' in the molecular era. Mol Ecol. 2010;19:3865-80.

7. Poulson TL, Culver DC. Diversity in terrestrial cave communities. Ecology. 1969:50:153-8.

8. Culver DC. The evolution of aquatic cave communities. Am Nat. 1976;110:945-57

9. Poulson TL, White WB. The cave environment. Science. 1969:165:971-81.

10. Janzen DH. Why mountain passes are higher in the tropics? Am Nat. 1967:101:233-49.

11. Futuyma DJ, Moreno G. The evolution of ecological specialization. Annu Rev Ecol Syst. 1988;19:207-33.

12. Huey RB, Kingsolver JG. Evolution of thermal sensitivity of ectotherm performance. Trends Ecol Evol. 1989;4:131-5

13. Peck LS, Webb KE, Bailey DM. Extreme sensitivity of biological function to temperature in Antarctic marine species. Funct Ecol. 2004;18:625-30.

14. Latella $L$, Bernabò $P$, Lencioni $V$. Distribution pattern and thermal tolerance in two cave dwelling leptodirinae coleoptera, cholevidae. Subterranean Biol. 2004;6:81-6.

15. Culver DC, Sket B. Hotspots of subterranean biodiversity in caves and wells. J Cave Karst Stud. 2000:62:11-7.

16. Culver DC, Deharveng L, Bedos A, Lewis JJ, Madden M, Reddell JR, et al. The mid-latitude biodiversity ridge in terrestrial cave fauna. Ecography. 2006;29:120-8
17. Faille A, Casale A, Balke M, Ribera I. A molecular phylogeny of Alpine subterranean Trechini. BMC Evol Biol. 2013;13:248.

18. Faille A, Ribera I, Deharveng L, Bourdeau C, Garnery L, Quéinnec E, et al. A molecular phylogeny shows the single origin of the Pyrenean subterranean Trechini ground beetles (Coleoptera: Carabidae). Mol Phylogenet Evol. 2010;54:97-106

19. Ribera I, Fresneda J, Bucur R, Izquierdo A, Vogler AP, Salgado JM, et al. Ancient origin of a Western Mediterranean radiation of subterranean beetles. BMC Evol Biol. 2010;10:29.

20. Cieslak A, Fresneda J, Ribera I. Life-history specialization was not an evolutionary dead-end in pyrenean cave beetles. P Roy Soc B Biol Sci. 2014;281:20132978.

21. Rizzo V, Comas J, Fadrique F, Fresneda J, Ribera I. Early pliocene range expansion of a clade of subterranean pyrenean beetles. J Biogeogr. 2013:40:1861-73

22. Hijmans RJ, Cameron SE, Parra JL, Jones PG, Jarvis A. Very high resolution interpolated climate surfaces for global land areas. Int J Climatol. 2005;25:1965-78

23. Kiehl J, Gent P. The community climate system model, version two. J Climate. 2004;17:3666-82.

24. Otto-Bliesner BL, Brady EC, Tomas R, Levis S, Kothavala Z. Last glacial maximum and holocene climate in CCSM3. J Climate. 2006;19:2526-44.

25. Salt RW. Principles of insect cold-hardiness. Annu Rev Ent. 1961;95:1190-202.

26. Lee Jr RE. A primer on insect cold-tolerance. In: Denlinger DL, Lee Jr RE, editors. Low temperature biology of insects. Cambridge: Cambridge University Press; 2010. p. 1-34.

27. Calosi P, Bilton DT, Spicer II, Votier SC, Atfield A. What determines a species' geographical range? thermal biology and latitudinal range size relationships in European diving beetles (Coleoptera: Dytiscidae). J Anim Ecol. 2010;79:194-204.

28. Sunday JM, Bates AE, Dulvy NK. Global analysis of thermal tolerance and latitude in ectotherms. P Roy Soc B Biol Sci. 2011;278:1823-30.

29. Hidalgo-Galiana A, Sánchez-Fernández D, Bilton DT, Cieslak A, Ribera I. Thermal niche evolution and geographical range expansion in a species complex of western mediterranean diving beetles. BMC Evol Biol. 2014;14:187

30. Calosi P, Bilton DT, Spicer Jl, Atfield A. Thermal tolerance and geographic range size in the Agabus brunneus group of European diving beetles (Coleoptera: Dytiscidae). J Biogeogr. 2008:35:295-305.

31. Sánchez-Fernández D, Calosi P, Atfield A, Arribas P, Velasco J, Spicer Jl, et al. Reduced salinities compromise the thermal tolerance of hypersaline specialist diving beetles. Physiol Entomol. 2010;35:265-73.

32. Arribas $P$, Velasco J, Abellán $P$, Sánchez-Fernández D, Andújar C, Calosi $P$, et al. Dispersal ability rather than ecological tolerance drives differences in range size between lentic and lotic water beetles (Coleoptera: Hydrophilidae). J Biogeogr. 2012;39:984-94.

33. Salgado JM, Blas M, Fresneda J. Coleoptera: cholevidae. In: Fauna Iberica. Vol. 31. Madrid: Consejo Superior de Investigaciones Científicas; 2008.

34. Fresneda J, Hernando C. Speonomus kryophilos n. sp. (Coleoptera, Cholevidae) nuevo Bathysciinae del Pirineo catalán. Ilerda Ciències. 1991;49:259-64.

35. Somero GN. Proteins and temperature. Annu Rev Physiol. 1995:57:43-68.

36. Davis AJ, Jenkinson LS, Lawton JH, Shorrocks B, Wood S. Making mistakes when predicting shifts in species range in response to global warming. Nature. 1998:391:783-6.

37. Kearney M. Habitat, environment and niche: what are we modelling? Oikos. 2006;115:186-91.

38. Sánchez-Fernández D, Aragón P, Bilton DT, Lobo JM. Assessing the congruence of thermal niche estimations derived from distribution and physiological data. a test using diving beetles. PLoS One. 2012;7:e48163.

39. Araújo MB, Ferri-Yáñez F, Bozinovic F, Marquet PA, Valladares F, Chown SL. Heat freezes niche evolution. Ecol Lett. 2013;16:1206-19.

40. Delay B. Milieu souterrain et écophysiologique de la reproduction et du développement des Coléoptères Bathysciinae hypogés. Mém Biospéol. 1978;5:1-349.

41. Frederich M, Pörtner HO. Oxygen limitation of thermal tolerance defined by cardiac and ventilatory performance in spider crab, Maja squinado. Am J Physiol Reg I. 2000;279:R1531-8.

42. Pörtner $\mathrm{HO}$. Climate change and temperature-dependent biogeography: oxygen limitation of thermal tolerance in animals. Nature. 2001;88:137-46.

43. McCue MD, De Los Santos R. Upper thermal limits of insects are not the result of insufficient oxygen delivery. Physiol Biochem Zool. 2013;86:257-65. 
44. Verberk WCEP, Bilton DT. Respiratory control in aquatic insects dictates their vulnerability to global warming. Biol Lett. 2013;9:20130473.

45. Moldovan OT, Jalžić B, Erichsen E. Adaptation of the mouth parts in some subterranean Cholevinae (Coleoptera, Leiodidae). Natura Croatica. 2004;13:1-18.

46. Paoletti MG, Beggio M, Dreon AL, Pamio A, Gomiero T, Brilli M, et al. A new foodweb based on microbes in calcitic caves: the Cansiliella (Beetles) case in Northern Italy. Int J Speleol. 2011;40:45-52

47. Lencioni V, Bernabò P, Latella L. Cold resistance in two species of cavedwelling beetles coleoptera: cholevidae. J Therm Biol. 2010;35:354-9.

48. Bernabò P, Latella L, Jousson O, Lencioni V. Cold stenothermal cavedwelling beetles do have an HSP70 heat shock response. J Therm Biol. 2011;36:206-8

49. Mermillon-Blondi F, Lefour C, Lalouette L, Renault D, Malard F, Simon L, et al. Thermal tolerance breadths among groundwater crustaceans living in a thermally constant environment. J Exp Biol. 2013;216:1683-94.

50. Eme D, Malard F, Colson-Proch C, Jean P, Calvignac S, Konecny-Dupré L, et al. Integrating phylogeography, physiology and habitat modelling to explore species range determinants. J Biogeogr. 2014;41:687-99.

51. Zachos J, Pagani M, Sloan L, Thomas E, Billups K. Trends, rhythms, and aberrations in global climate 65 Ma to present. Science. 2001;292:686-93.

\section{Submit your next manuscript to BioMed Central and take full advantage of:}

- Convenient online submission

- Thorough peer review

- No space constraints or color figure charges

- Immediate publication on acceptance

- Inclusion in PubMed, CAS, Scopus and Google Scholar

- Research which is freely available for redistribution 